\title{
MULHERES PEDINDO JUSTIÇA: processos criminais no vice- reinado do Rio da Prata (Século XVIII)
}

\author{
Rafael Ruiz*
}

\begin{abstract}
RESUMO: A finalidade deste artigo é a de procurar analisar e mostrar algumas características singulares e próprias nas formas de administrar a justiça no Vice-reinado do Prata, no final do século XVIII. Apresento aqui três processos de violência doméstica que têm duas características específicas: a extrema celeridade na tramitação dos mesmos e o exercício do arbítrio dos juízes não apenas no andamento das diligências processuais, mas também nas sentenças. Essa forma de proceder estava baseada numa maneira de entender o mundo jurídico, típica da Idade Moderna e que ia muito além da simples aplicação da lei, tendo como elementos decisivos para a própria administração da justiça a equidade, a clemência e o direito, este último entendido como aquilo que, de fato, era visto como justo ou adequado por parte dos juízes.
\end{abstract}

PALAVRAS-CHAVE: História da justiça; Violência doméstica; América espanhola; Século XVIII.

\section{Women asking for justice: criminal proceedings in the Viceroyalty of the Río de la Plata (Century XVIII)}

ABSTRACT: The main objective of this work is to analyze and to show some singular and peculiar characteristics in the ways of administering justice in the Viceroyalty of the Río de la Plata in the late eighteenth century. I present here three domestic violence processes that have two specific characteristics: extreme celerity in their processing and the exercise of judges' discretion not only in the course of procedural steps, but also in the sentences. These procedures were based on a way of understanding the juridical world, typical of the Modern Age and that went far beyond the simple application of the law, having as decisive elements for the own administration of justice the equity, the mercy and the right, the latter being understood, in fact, as fair or adequate by the judges.

KEYWORDS: History of Justice; Domestic violence; Spanish America; Eighteenth century.

\section{Mujeres pidiendo Justicia: Procesos criminales en el Virreinato del Río de la Plata (siglo XVIII)}

RESUMEN: La finalidad de este artículo es la de intentar analizar y mostrar algunas características singulares y propias en las formas de administrar la justicia en el Virreinato del Río de la Plata, a finales del siglo XVIII. Presento aquí tres procesos de violencia doméstica que tienen dos características específicas: la extrema rapidez en el trámite procesal y el ejercicio del arbitrio de los jueces no sólo en las diligencias, sino también en las sentencias. Esa forma de proceder estaba fundamentada en una manera de entender el mundo jurídico, típica de la Edad Moderna, y que iba mucho más allá de la mera aplicación de la ley, teniendo como elementos decisivos para la administración de la justicia la equidad, la clemencia y el derecho, éste entendido como aquello que, de hecho, era visto como justo o adecuado por parte de los jueces.

PALABRAS-LLAVE: Historia de la Justicia. Violencia doméstica. América española. Siglo XVIII.

\footnotetext{
*Professor Doutor Associado de História da América (Escola de Filosofia, Letras e Ciências Humanas da Universidade Federal de São Paulo). Coordenador do Núcleo de estudos ibéricos. O autor agradece à FAPESP pela ajuda concedida para realizar esta pesquisa. Contato: Estr. do Caminho Velho, 333 - Jardim Nova Cidade, 04021-001, Guarulhos - SP, Brasil.rafarui@hotmail.com
} 


\section{Os expedientes judiciais como fontes para a Historiografia}

É relativamente recente a preocupação dos historiadores com os processos civis e criminais como fontes de pesquisa. $\mathrm{O}$ trabalho com expedientes judiciais como fontes para a pesquisa e conhecimento histórico é uma tarefa que demanda uma série de cuidados metodológicos por parte dos historiadores.

Nesse sentido, Viviana Kluger, num artigo de 2009, advertia da necessidade de não tomar o todo pela parte, devido ao fato de que as informações obtidas se referem sempre a "situações-limite", refletindo apenas um lado da moeda, embora nem por isso "tira valor da

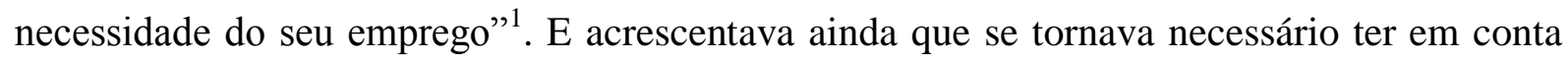
que todo processo judicial "capta apenas uma parte da transgressão, a do incumprimento, porque uma grande quantidade de causas nem chegava às instâncias judiciais" e, a o mesmo tempo, o que se afirma neles "nem sempre é a expressão genuína do que os involucrados sentem ou percebem, porque está mediatizada pela intervenção dos advogados, dos juízes e dos escrivães",2.

Nessa mesma linha, Mônica Ghirardi, num artigo de 2007, procurou dar conta dos trabalhos e pesquisas realizados com a finalidade de analisar "o possível êxito ou fracasso da aplicação do modelo de família cristã na Iberoamérica, de acordo com as prescrições da Igreja católica"3. E, ao tratar sobre a questão dos maus tratos, da paz familiar e da separação dos corpos, observava que uma das fontes privilegiadas para esses casos poderiam ser os processos civis ou criminais que podiam ser encontrados nos arquivos. Como a própria autora afirmava "as análises realizadas dão conta de que a mulher tinha um papel de protagonista nas solicitudes de separação, embora pareça uma contradição no contexto ideológico da sociedade patriarcal que lhe determinava um papel de inferioridade, subordinado e dependente do homem"4.

Por outro lado, Ann Twinan, questionava-se sobre as diferentes análises que poderiam ser feitas a partir da constatação feita por Ghirardi. Tentando explicar os rumos das pesquisas historiográficas dentro do âmbito da história da família, advertia que nos encontrávamos dentro de um terreno muito ambíguo e "com problemas metodológicos inerentes a qualquer análise de processos: Podemos interpretar esses processos legais como provas do poder das mulheres como litigantes contra maridos ou amantes opressivos? Por outro lado, é possível ver aqui manifestações de fraqueza, tendo em conta que a posição das mulheres era tão degradada dentro do lar que eram forçadas a procurar ajuda fora? "

No mesmo sentido, e no mesmo livro, Ghirardi perguntava-se, partindo da análise dos processos judiciais, “até que ponto pode considerar-se que as prescrições tridentinas foram 
assimiladas aos comportamentos das famílias ibero-americanas coloniais?"6 e, referindo-se à obra de Pilar Gonzalbo, Familia y orden colonial, acrescentava que a autora fazia referência “às transgressões do paradigma familiar único construído sobre a base da conjunção entre a legislação castelhana e as pautas da moral cristã e, em contraste, uma multiplicidade de práticas, qualificando os desvios do ideal como frequentes e rotineiros, enfatizando a tolerância e até a indiferença com que eram assumidos comportamentos transgressores, nos quais as autoridades eclesiásticas e seculares intervinham apenas quando os fatos tornavam-se públicos",

Por outro lado, abrindo outra perspectiva, Fuentes Barragán, num artigo bem mais recente tratando sobre o tema específico das "amizades ilícitas" no Vice-reinado do Prata, no fim da época colonial, e consultando as mesmas fontes processuais que utilizo neste artigo, no Archivo Histórico de la Provincia de Buenos Aires, considerava que nessa época a realidade foi se impondo de maneira completamente diferente àquilo que era querido e procurado tanto pela Igreja como pela Coroa, de maneira que "o elemento mais distante, mais problemático e mais carregado de entidade própria foi precisamente o dos afetos. O contato pessoal tinha lugar, portanto, num marco rígido, mas vulnerável, e especialmente desordenado" ${ }^{8}$. E, em outro artigo, também de 2015, o autor declarava que a cidade de Buenos Aires, "na sua periferia tinha uma dinâmica e mobilidade social com variedade étnica e mestiçagem e mais flexibilidade na legislação", configurando-se como um campo privilegiado de estudo para os historiadores porque "foi uma das áreas de maior crescimento demográfico durante a última época do período colonial"”.

Por sua parte, Osvaldo Barreneche, num artigo de 1993 sobre os delitos e desvios sexuais em Buenos Aires na passagem do século XVIII para o XIX, esclarecia que as decisões judiciais se caracterizaram como "um processo de análise onde se interpretava a palavra real dos protagonistas" 10 , de maneira que os processos eram elaborados caso a caso, sendo que para uma mesma tipificação legal do delito, poderíamos encontrar tanto condenações como absolvições, dependendo de cada caso ${ }^{11}$.

Por último, gostaria de citar outros dois historiadores. O historiador argentino, Alejandro Agüero, com as suas análises sobre a realidade processual de uma região periférica como era Córdoba de Tucumán, e o historiador espanhol Pedro Ortego Gil, com as suas pesquisas sobre o perfil do juiz e o arbítrio judicial na Monarquia Hispânica.

Agüero procurava estabelecer um diálogo com a tese dominante, estabelecida há tempo pelo historiador espanhol Tomás y Valiente, para quem a consolidação da monarquia 
absoluta hispânica esteve profundamente apoiada na lei penal e na sua aplicação rigorosa e quando surgia um obstáculo ou algum desvio entendia-se que o problema radicava precisamente na condição local e periférica. Agüero, porém, procurava mostrar como, além da lei régia, existiam muitas outras fontes e, por esse motivo, as decisões e sentenças "não eram necessariamente consequência do particular contexto periférico, ou supervivências de formas comunitárias, mas efeitos da operabilidade de certos princípios e formas de raciocínio normativo que, apesar das mudanças dos séculos modernos, não tinham perdido vigência"12.

Ortego preocupava-se por mostrar que o que era entendido como "direito" ultrapassava em muito a lei régia. Como afirmava em um artigo de 2007, “O Direito de Castela, desde uma perspectiva meramente descritiva e básica, estava configurado pela lei do rei (Partidas e Recopilações), pelas interpretações manuscritas e impressas dos (grandes) juristas -graças aos quais o Direito em seu conjunto evoluiu-, pelas decisões dos altos tribunais -sobretudo nos territórios onde se gerou uma literatura decisionista- e através do estilo judicial e do costume -que por variadas razões estava limitada territorialmente-, sem obviar as manifestações derivadas da aplicação não contenciosa do Direito. Em definitivo, um único Direito composto de diferentes elementos"13.

Por outro lado, em outro artigo, publicado em 2012, tratava das relações entre o direito civil e o canônico, entre o juiz e o confessor e entre os delitos e pecados, afirmando que "para entender o modo de resolver as causas por parte dos juízes seculares convinha olhar para o direito canônico"14. E acrescentava que essas profundas imbricações trouxeram como consequência que os juízes criminais orientassem as suas sentenças, de acordo com o seu arbítrio, procurando a equidade e a misericórdia ${ }^{15}$

$\mathrm{O}$ artigo aqui apresentado parte da análise dos processos criminais na Real Audiência de Buenos Aires, no fim do século XVIII, e procura mostrar as peculiaridades e singularidades da prática processual na administração da justiça, inserindo-se dentro da história da justiça e não propriamente dentro da história do direito.

Não se trata, portanto, de analisar as instituições nem o ordenamento processual, mas verificar como, nos casos concretos, se realizavam os processos e se sentenciavam os casos. Nesse sentido, segue a linha apontada por Silvia Lara e Joseli Mendonça, para quem há um crescente interesse por parte da historiografia com relação aos aspectos referentes "à definição e aplicação das leis, à composição e funcionamento das instituições judiciárias, à atuação de profissionais da justiça (advogados, juízes), à definição de doutrinas"16, em grande medida, de acordo com as autoras, porque "o direito, o justo, o legal e o legítimo formam campos 
conflituosos, constitutivos das próprias relações sociais: campos minados pela luta política, cujos sentidos e significados dependem das ações dos próprios sujeitos históricos que os conformam"17.

O primeiro deles é um crime de estupro que não chegou a formalizar-se como um processo ordinário. $\mathrm{O}$ alcalde $^{18}$ ordinario fez as diligências para substanciar a informação sumária, de forma reservada, e enviou uma carta, também reservada, à Real Audiência, sugerindo a pena correspondente. $\mathrm{O}$ segundo refere-se a um crime de maus tratos que a vítima tentou iniciar junto do juiz competente, mas a queixa não foi recebida. Procurou uma jurisdição próxima da cidade de Buenos Aires e entrou, novamente, com a mesma queixa e, desta vez, o alcalde acolheu a petição. Contudo, uma vez comissionado por parte da Audiência para acompanhar o processo, não deu a sentença final e a Real Audiência interveio no processo e citou as partes para encaminhar a causa para sentença e conclusão na sala da Audiência. E o último trata de um processo de divórcio em que as formas procedimentais correspondem a um processo ordinário, contudo, depois da fase probatória, a vítima propôs à Real Audiência desistir do processo desde que o marido aceitasse uma série de condições impostas pela vítima. A Audiência concordou com a proposta e, inclusive, formalizou a sua sentença, mesmo com a desistência, impondo ao réu uma pena pecuniária que nem sequer tinha sido solicitada pela vítima.

São processos marcados pela celeridade da sua tramitação e onde se manifesta claramente o arbítrio dos juízes. Um arbítrio, porém, que não é "arbitrário", mas que se insere na praxe processual do Antigo Regime onde muitos outros elementos, além da lei, influenciavam na tomada de decisão, dentre eles a equidade, a compaixão e o direito.

\section{Os processos criminais no ordenamento jurídico de Castela}

De acordo com María Paz Alonso, autora de uma monografia detalhada sobre o processo penal em Castela, durante os séculos XIII ao XVIII, não houve muitas normas nem mudanças significativas nas leis processuais a partir dos Reis Católicos (1492), de maneira que "no plano normativo quase que não houve inovações de importância que alteraram o esquema procedimental das Partidas"19.

Os processos podiam seguir um procedimento "ordinário" ou bem um procedimento "simplificado". A simplificação do rito ordinário foi uma tarefa realizada, de acordo com a autora, pelos próprios juízes "que apoiaram e canalizaram a progressiva extensão da ordem 
simplificada, ajudados pelos autores práticos que com as suas obras contribuíram a divulgar a nova ordem procedimental" 20 .

O procedimento ordinário constava de três fases: "uma fase inicial ou sumária, o juízo plenário e a sentença" ${ }^{21}$. Era na fase sumária que se procurava esclarecer os elementos e circunstâncias do delito e identificar os possíveis autores do mesmo, sendo que, frequentemente, o juiz podia ditar medidas cautelares, como a prisão do acusado e o sequestro dos seus bens, como forma de garantir a eficácia inquisitiva dessa fase. Era também nessa fase que o acusado era interrogado pela primeira vez, na presença do juiz ${ }^{22}$.

Uma vez encerrada a fase sumária, começava o juízo plenário em que se apresentava formalmente a acusação e tinha duas fases: "a primeira para determinar as posições das partes, com os escritos de acusação, contestação, réplica e contra-réplica, e uma segunda parte probatória, a cada uma das quais se dava fim com as respectivas conclusões, para prova ou para sentença" 23 .

A última fase, a sentença, era dada pelo juiz, depois de examinar as atas processuais, “com concisão de palavras e sem nenhuma fundamentação expressa, o juiz emitia a sua sentença absolvendo ou condenando o réu" 24 .

A principal preocupação da Coroa, desde as Partidas, de Alfonso X, era a duração dos processos, entre outros motivos porque desde a fase inicial sumária, o réu poderia encontrarse em prisão, como de fato acontecia com frequência. O prazo máximo indicado nas Partidas era de dois anos, contudo, raramente esse prazo conseguia ser observado, inclusive, muitas vezes "uma vez concluídos, [os processos] podiam permanecer meses e meses sem sentenciar," 25 .

O procedimento "simplificado" caracterizava-se principalmente por estabelecer uma série de prazos preclusivos, ou seja, inadiáveis, para os diferentes procedimentos e fases do processo. Em termos concretos, condensavam-se num prazo extremamente curto "a confissão do réu, a ratificação das testemunhas da informação sumária, a acusação formal do fiscal, a contestação do réu, a apresentação do interrogatório e testemunhas do réu para destruir as acusações que aparecem contra ele na sumária" ${ }^{26}$, passando-se mais rapidamente para a sentença.

Na opinião de Paz Alonso, o procedimento "simplificado", embora possa favorecer o réu, dado que muitas vezes podiam ser "intermináveis os meses e anos em que podia ficar submetido aos rigores de uma prisão preventiva muito dura" ${ }^{27}$, por outro lado, dificultava a defesa do réu, ao reduzir os prazos de defesa. A autora considera, dentro da lógica do Antigo 
Regime, que um processo mais simples "era muito mais eficaz para conseguir a repressão do crime do que o procedimento ordinário" ${ }^{\text {28 }}$.

Parece-me que a autora compartilha da visão sobre o processo criminal estabelecida pelo famoso historiador Tomás y Valiente, para quem um sistema processual eficaz e repressivo era central para o exercício da Monarquia absoluta. Contudo, diante das pesquisas e dos trabalhos mais recentes sobre o assunto, e principalmente a obra já indicada de Agüero, e tendo em conta a análise pessoal que realizei nos processos consultados, considero que não cabe descartar a hipótese de que o processo simplificado permitia uma margem de flexibilidade e de manobra muito maior aos juízes que podiam, sim, estar interessados apenas na pronta condenação dos réus, contudo também podiam procurar que uma rapidez maior nos processos tornasse possível uma sentença mais justa.

\section{Os processos criminais no Vice-reinado do Rio da Prata no fim do século XVIII}

A cidade de Buenos Aires teve um grande aumento demográfico no começo da época dos Bourbons, na segunda metade do século XVIII. Em 1783, por Cédula Real de 14 de abril, foi criada a Real Audiência de Buenos Aires, com jurisdição sobre um extenso território que compreendia o Paraguai, as cidades de Córdoba, Salta, Montevideu, Missões e a capital, Buenos Aires. Era composta por cinco Ouvidores, um deles o Regente da Audiência, e dois fiscais, um para as causas civis e outro para as criminais ${ }^{29}$. Era, como no caso das Reais Audiências de Novo México e do Peru, um tribunal de apelação para as causas civis e criminais que fossem sentenciadas pelos juízes inferiores e, por determinação da própria Audiência, era obrigatória a consulta de todas as causas criminais, com penas capitais ou aflitivas, realizadas na primeira instância, ou seja, de ofício, o Alcalde ordinario deveria, mesmo que não houvesse apelação da parte lesada, elevar à Audiência o processo sentenciado e concluído ${ }^{30}$.

Um ponto que me parece importante destacar, porque embora conhecido nem sempre é levado em conta, é a opinião de María Rosa Pugliese quando, ao falar sobre a função dos juízes de primeira instância, insiste na ideia de que na América hispânica "privilegiou-se mais uma ordem moral do que uma ordem técnica, considerando que quem fosse nascido do próprio ‘comum' poderia resolver melhor os problemas por e entre iguais" ${ }^{31}$. E, nesse sentido, a sua função não era apenas o exercício de um cargo, mas uma verdadeira obrigação de consciência e, por outro lado, a sua decisão não se restringia à simples aplicação da lei, mas a uma deliberação baseada principalmente em princípios e considerações morais e religiosos. 
A consequência mais relevante dessa maneira de pensar era precisamente que se considerava como "bom juiz" aquele que, precisamente por ser mais um e igual a todos os outros, compartilhasse do sentido do justo e do direito que era próprio daquela localidade e que se expressava muito mais pelos costumes, a exemplaridade e a equidade do que pelo conhecimento técnico da legislação. Por isso que os alcaldes eram eleitos -dois cada anodentre os próprios vizinhos ${ }^{32}$.

Dos cem processos consultados no “Archivo Histórico de la Provincia de Buenos Aires 'Ricardo Levene"” para realizar este artigo, pude verificar que aproximadamente um terço corresponde à classificação apontada por Alonso como "procedimento ordinário", seguindo as três fases do processo, como em Castela, e cumprindo rigorosamente os prazos estabelecidos, tanto para defesa como para acusação. Os outros 75 encaixam-se dentro do rito de "procedimento simplificado".

Iniciavam-se ou bem, de ofício, por parte do Alcalde ordinario, ou bem por demanda verbal da vítima, depois reduzida a termos. Normalmente era uma folha ofício onde se detalhava a denúncia e conhecia-se como "cabeça do Processo".

O Alcalde ordinario, então, ordenava as diligências necessárias para "substanciar a Sumária": tomava declaração ao acusado e à vítima, e ouvia as testemunhas para formar uma convicção sobre a gravidade do caso. Há muitos processos em que o denunciado era preso preventivamente e se procedia ao decreto de embargo dos seus bens para assegurar as custas do processo e as possíveis multas.

Encerrado o rito sumário procedia-se à segunda fase, o juízo plenário, onde se formalizava a acusação. É nesta fase que se encontra a diferença entre o procedimento ordinário e o simplificado. Os processos que corriam conforme o rito ordinário, começavam esta fase pelo interrogatório de todos os envolvidos (vítima, réu e testemunhas de defesa e acusação) de acordo com um questionário prévio realizado pelos advogados das partes.

Dependendo do número de testemunhas, o número de folhas processuais podia ser bastante grande. O questionário constava de uma série de perguntas sobre "questões gerais": a idade, o estado civil, o lugar de nascimento e residência, a profissão das mesmas e, depois, passava-se para as "questões particulares": no caso do réu, se sabia por que motivo estava preso, se de fato fez o que a vítima disse que fez, por que motivos agiu daquela maneira, se sabia que era pecado e crime o que praticara; no caso da vítima, o que foi que aconteceu naquele dia, como foi que o réu se comportou com ela, o que foi que disse ou fez, se pediu ou não pediu ajuda; no caso das testemunhas, se viu ou ouviu o que se passou, se conhecia o réu 
e a vítima e desde quanto tempo. Todas as respostas eram anotadas e, acabado cada depoimento, era lido por inteiro, palavra por palavra, e se deixava anotado se foi ou não ratificado pelo depoente e, finalmente, era assinado por ele ou, o que era muito comum, por outra pessoa no caso de não saber escrever. Assinavam também o juiz e o escrivão.

Enviavam-se, então, os autos ao Fiscal da Sua Majestade no criminal para que, vistos os depoimentos, tomasse uma posição, formalizasse ou não uma acusação e pedisse uma pena. Encaminhava-se, então, todo o processo para o defensor que podia ser um particular, o que era muito raro, ou, então, um dos Defensores ou Protetores de Pobres, que apresentava a defesa do réu.

A partir desses dois documentos, podia acontecer que se pedisse um novo interrogatório de todas ou de algumas das testemunhas das partes, principalmente quando se verificava uma contradição entre os depoimentos ou mesmo uma nova confissão das partes. Nesses casos, novamente o juiz e o escrivão "reconvenían", ou seja, voltavam a questionar a pessoa indicada. Nessa altura, as pessoas interrogadas podiam ratificar suas declarações anteriores ou modificá-las.

Os autos, então, eram enviados, de novo, para o Fiscal e o Protetor de Pobres fazerem as suas "réplicas" e, então, normalmente se considerava que o processo estava pronto para sentença.

Quando o rito era realmente "ordinário", os simples transcursos dos prazos previstos para cada um desses momentos processuais tornavam o processo mais demorado. A simplificação consistia precisamente na eliminação de alguns procedimentos. Assim, por exemplo, a maior parte dos processos consultados não tinham o interrogatório das partes nem das testemunhas na forma de questões prévias "gerais" ou "particulares". Todas elas eram ouvidas perante o juiz e o escrivão e relatavam o que sabiam ou queriam dizer, encurtando dessa forma o tempo processual.

Como disse, a Real Audiência de Buenos Aires, logo depois da sua instalação, passou a exigir que, como a grande maioria dos juízes ordinários eram leigos e não tinham conhecimento da disciplina e ciência jurídica, fosse nomeado um Assessor Letrado para auxiliá-lo e que formalizava a sentença em forma de sugestão ${ }^{33}$, ou seja, fazia um resumo da causa, explicava o que pedia uma e outra parte, levantava considerações sobre as circunstâncias que envolviam as partes e os fatos, e sugeria um tipo de pena. A seguir, o processo era enviado ao juiz que, em termos simples e diretos, dava a sentença. Umas vezes dizia explicitamente que acolhia por inteiro o parecer do Assessor, outras, explicava uma ou 
outra circunstância relevante ou enunciava em algumas linhas o seu parecer e absolvia ou condenava, determinando a pena em concreto.

Sempre, de ofício, essa sentença era, ainda, enviada à Real Audiência de Buenos Aires que, de forma bem direta, sem nenhuma outra consideração, salvo raras exceções, confirmava ou revogava a sentença do juiz ordinário.

Tanto de uma parte quanto de outra podia, ainda, haver apelação ao mesmo Tribunal. A parte interessada devia expor os motivos de por que queria apelar e, uma vez concedida, apresentava uma argumentação em que tentava mostrar a injustiça da sentença proferida. Essa apelação era enviada também à outra parte para que se manifestasse sobre a mesma. Depois disso, o Tribunal ditava sentença definitiva.

\section{Os processos analisados: Celeridade dos processos e arbítrio dos juízes}

A Monarquia Hispânica estava preocupada com as delongas processuais. No Libro de Las Partidas, no século XIII, limitava-se a duração dos processos penais a dois anos, mas essa determinação legal já não se observava no século $\mathrm{XVI}^{34}$. Ainda no século XVIII a preocupação com a celeridade dos processos foi objeto da Real Cédula de Carlos III, de 23 de junho de 1768, determinando-se que as sentenças não fossem motivadas ${ }^{35}$ para evitar demoras, perdas de dinheiro e dilações inúteis ${ }^{36}$.

De acordo com Mariluz Urquijo, um dos historiadores que mais estudaram as Audiências Reais na América espanhola e, concretamente, a de Buenos Aires, o momento da instalação desse Tribunal no Vice-reinado da Prata coincidiu com as tentativas de reforma por parte da Coroa com relação ao direito penal, e especificamente, às penas aplicadas, procurando diminuir o seu rigor e, em concreto, eliminar a pena de morte ${ }^{37}$. No caso concreto, esperava-se da Real Audiência que colocasse "ordem e concerto" nas práticas erradas realizadas pelos juízes de primeira instância, principalmente no que dizia respeito "às práticas dilatórias, e conduzir-se de acordo com “ o que devem observar conforme ao direito e sem erros" 38 .

No seu artigo, o autor considerava que o maior problema na administração da justiça consistia no fato de que muitos alcaldes ordinarios impunham penas aos réus conforme o seu próprio critério e vontade, muitas vezes por meio de açoites, por considerá-los mais eficazes, para manter a ordem, do que as penas de prisão ou as pecuniárias e, com frequência, a situação era paradoxal: umas vezes, os processos eram muito rápidos, com a consequente 
diminuição dos direitos de defesa dos réus, e outras, muito longos, deixando que os réus ficassem por muito tempo nas prisões ${ }^{39}$.

Das várias medidas que foram adoptadas quase que imediatamente pela Audiência, merecem ser destacadas, pelo menos, três delas: a obrigação de encaminhar para a Real Audiência, de ofício, o processo concluído e sentenciado na primeira instância, nos casos de delitos graves, lesões e morte; a orientação de que, seguindo os prazos previstos, o processo não sofresse dilações desnecessárias e a obrigatoriedade de que os alcaldes ordinarios fossem assessorados por um Assessor letrado. Conforme ressaltam Viviana Kluger e María Rosa Plugiese nos artigos já citados, estava em marcha, de forma talvez um pouco lenta, mas progressiva, a tentativa de transformar a justiça lega em justiça letrada.

Os processos aqui analisados foram escolhidos por apresentarem um tipo de peculiaridade específica em cada caso, deixando claramente manifestas essas duas características, a celeridade dos processos e o arbítrio nas decisões judiciais.

O primeiro deles, de Juana Inés contra seu tio Alejandro Illescas, correu de forma "reservada" pelas graves circunstâncias que o caso apresentava. Foi iniciado aos 26 de junho de 1788 e ficou concluso a $1^{\circ}$ de setembro do mesmo ano, pouco mais de dois meses depois do seu início ${ }^{40}$.

O segundo, de Pasquala González contra seu marido Leandro Roldán, apresentava uma questão de competência do juiz de primeira instância. Foi iniciado aos 23 de setembro de 1789 e concluso aos 9 de fevereiro de 1790 , quase cinco meses depois ${ }^{41}$.

E o terceiro, de Manuela Melo contra seu marido Sebastián Pérez de Caravaca, é uma ação de divórcio por maus tratos, em que a vítima, no meio do processo, propôs desistir da ação desde que o marido aceitasse uma série de condições. O Ouvidor, juiz da causa, antes de proferir a sentença, determinou que essas condições fossem aceitas pelo marido, que estava na prisão, e multou o réu em 50 pesos, coisa que não foi solicitada nem pelo Fiscal, nem pela vítima. Foi iniciado no do dia 13 de novembro de 1786 e teve a sua sentença final aos 27 de março de 1787 , pouco mais de quatro meses depois de começado ${ }^{42}$.

\section{Juana Inés Illescas: que por Deus a deixasse viver}

Trata-se de um caso de estupro incestuoso praticado pelo tio da vítima, Alejandro Illescas, de 30 anos, contra sua sobrinha de 12 anos, Juana Inés. O delito tem as características de crime continuado, porque foi cometido sem interrupção até o momento da denúncia, 
quando Juana Inés contava já com 16 anos. Foi instaurado a partir de uma denúncia anônima perante o alcalde ordinario de $1^{\mathrm{o}}$ voto, Dom Manuel Antonio Warnes.

$\mathrm{Na}$ verdade, não se pode falar propriamente de processo, no sentido legal e ordinário do mesmo. Conforme atesta o escrivão na primeira folha do processo, como o acusado e o pai da moça eram personagens conhecidas publicamente na cidade, já que don Phelipe Illescas, pai de Juana Inés, tinha sido Alcalde de la Santa Hermandad, o alcalde "mandou que se fizesse uma sumária informação reservada e secreta de todos estes fatos e uma vez concluída fossem informados os Senhores Presidente e Ouvidores desta Real Audiência” (f. 1r). A seguir, o alcalde, como explicava na carta reservada que dirigiu à Real Audiência, mandou colocar na prisão Alejandro Illescas, de forma preventiva, e diante do fato de que a moça ficara grávida, determinou que fosse encaminhada

na casa dos Santos Exercícios até que se verificasse o parto. Desse modo, evitar-seia que D. Phelipe soubesse da sua desonra e da honra da sua casa e com a segurança de Alexandro no cárcere evitava-se também que houvesse algum quebranto" (f.6v).

A Sumária foi formada apenas pelas confissões da vítima e do réu. Juana Inés declarou, sob juramento, que morava na casa dos pais e estava sob os cuidados da avó e que, quando era de idade de 12 anos, o seu tio Alejandro surpreendeu-a na cozinha e "como a encontrou sozinha e carregou-a nos braços e a deitou sobre uma cama, onde, sem embargo da sua resistência, desflorou-a por força e contra a sua vontade” (f. 4r).

Durante cinco anos o seu tio ameaçava-a continuamente, umas vezes com gritos e ordens, outras com faca e, mesmo quando a menina se encontrava acompanhada da sua avó, o tio levava-a para outro quarto e "se por casualidade a sua avó ouvia algum barulho ou suas vozes" (f. 4r), o tio tranquilizava a avó dizendo que essa gritaria toda era porque a sobrinha era rebelde e não queria obedecer-lhe e que ficava com vontade até de matá-la.

Juana Inés passou a viver com medo até de sair, porque sabia que muitas vezes o tio a esperava, quando ia procurar água no rio, para estuprá-la novamente. Nas suas palavras, o tio dominava-a completamente e

\begin{abstract}
nunca teve ânimo de contá-lo ao seu pai por pouca reflexão" e porque "ficou temerosa de que a matasse, como o tio prometera fazê-lo se contasse qualquer coisa para alguém. E que, em todos esses cinco anos, esgotada pelo proceder do seu tio, pedia-lhe, por Deus, que a deixasse viver e que, se possível, que não voltasse mais a olhar para ela, porque não podia mais nem confessar com espírito sossegado e tranquilo (f. $4 \mathrm{v})$.
\end{abstract}

O tio defendeu-se alegando que a sobrinha consentiu voluntariamente porque nem gritou, nem deu vozes, sendo que os familiares estavam nos quartos vizinhos. Juana Inés já 
tinha confessado que não reagira da primeira vez porque estava cheia de medo, pensando que o tio acabaria por matá-la, e das outras vezes, além dessa ameaça continuada, também começou a pensar que não sabia mais como falar com o pai, que poderia, por sua vez, querer matar o tio, ou mesmo a ela. E também porque ficara preocupada com a reação da sua mãe.

Com ambas as confissões, o juiz enviou a sumária para o Fiscal do crime, Marquez de la Plata, aos 8 de agosto de 1788, que reconheceu que, "por pouco que se meditar no diminuto sumário que foi escrito advertir-se-á que não há prova positiva” (f.8v) nem do estupro, nem da violência e nem das ameaças a que a vítima se referira, contudo o Fiscal considerava que se deveria proceder conforme "a um prudente e justificado arbitrio, de acordo com as circunstâncias do caso" e que, portanto, tendo em conta "a reta administração da Justiça dos juízes e Tribunais desta Capital era de se presumir que o tio fosse o sedutor diante da fraqueza do sexo e da idade da sobrinha [...] mesmo prescindindo da obscuridade e da falibilidade das provas" (f.8v). Solicitava, então, a pena de uma "multa considerável e um efetivo desterro com as convenientes precauções" (f.8v) para evitar que os fatos fossem do conhecimento do povo e, mais ainda, dos pais e familiares.

O alcalde Warnes, no seu informe reservado, aos 4 de Agosto de 1788, explicou aos ouvidores da Real Audiência que tinha decidido não formalizar um processo em regra para evitar que o caso fosse do conhecimento público "porque ainda não se tinha chegado a propagar o caso como se propagaria se se formasse em tela de juízo" (f.7r) e que era da opinião de que o tio fosse condenado a cinco ou seis anos de desterro a Montevidéu, tendo em conta que o crime ainda estava oculto (f.7r).

Todo o processo de Juana Inés consta de apenas dez folhas, frente e verso. Os "autos processuais" foram tão só as confissões do réu e da vítima. Não houve declarações de testemunhas nem procedimentos probatórios. Parece-me que não pode ser considerado nem um procedimento ordinário, nem simplificado. Trata-se, sim, de um processo "sui generis", em que da fase sumária passou-se para a sentença, mas não por parte do juiz competente -no caso, o alcalde ordinario- e sim pela Real Audiência.

Depois de ouvido o Fiscal, o juiz em lugar de dar uma sentença enviou uma carta reservada à Real Audiência propondo uma pena arbitrária e indeterminada de desterro por cinco ou seis anos. E o Tribunal, à margem da última folha da carta reservada do juiz Warnes, anotou a sentença, rubricada pelos cinco Ouvidores, condenando Alejandro Illescas ao desterro à cidade de Montevidéu, tendo em conta "sua desordenada conduta, nenhuma 
ocupação nem exercício suficiente para remover o conceito que se tem formado dele de vago e mal arranjado" (f.10v).

A pena ordinária para delitos dessa natureza era a pena de morte, contudo, de acordo com a doutrina, para impor tal tipo de pena era necessário que as provas fossem mais claras do que a luz do meio dia. O "processo", como afirmava o Fiscal do crime, carecia de provas e, portanto, a imposição da pena tornava-se arbitrária. Contudo, o que chama a atenção neste processo é não apenas que o alcalde ordinario não sentenciou, mas que o próprio Tribunal não concretizasse o tempo a que fora desterrado.

Poderia pensar-se ou bem em uma certa leniência por parte do Tribunal, ou, como alguns historiadores que comentamos acima, em uma vontade de punir e castigar de forma caprichosa ou absolutista. Contudo, parece-me que o motivo dessa indeterminação da pena poderia também ser explicado pela influência da teologia e do direito canônico que transferia aos juízes civis e criminais uma motivação de clemência e de misericórdia, procurando a conversão do réu muito mais do que a sua punição. Nesse sentido, parece-me que se entende melhor as providências finais adotadas pela Real Audiência: Don José Cabeza Enríquez, um dos Ouvidores do Tribunal, dirigiu-se diretamente a Montevideu para transmitir oralmente ao Governador da cidade, Don Joachin del Pino, ordens e providências que deveriam ser adotadas com relação ao réu, insistindo para que todo o processo fosse mantido em segredo de justiça (f. 10v). E, no dia $1^{\circ}$ de setembro de 1788, o Governador acusava recebimento da informação transmitida pelo Ouvidor.

\section{Pasquala Gonzalez: “Dava-me com força açoites, pauladas, bofetadas e pontapés”}

Trata-se de um caso de violência doméstica, em que a vítima, de 40 anos, queixava-se dos maus tratos a que o marido, de 50, a submetia de forma contínua. O processo apresenta uma particularidade interessante: a vítima tinha entrado com uma queixa na jurisdição do seu domicílio, em San Nicolás de los Arroyos, contudo, o Alcalde de la Santa Hermandad, juiz ordinário da povoação, não lhe deu atenção nem recebeu a demanda. Aconselhada pelo vigário da paróquia de San Nicolás, Pasquala apresentou uma nova queixa na cidade de Santa Fé, próxima de Buenos Aires. O alcalde de Santa Fé acolheu a denúncia e deu as providências para formalizar a Sumária, citando seis testemunhas, conforme o pedido de Pasquala.

Quando o Fiscal teve de se manifestar, depois de recebida a Sumária, dirigiu-se à Real Audiência e não ao alcalde de Santa Fé, explicando que, diante das graves circunstâncias em que os fatos tinham acontecido e, mais ainda, diante da recusa do alcalde competente -de San 
Nicolás de los Arroyos- e a acolhida da demanda por parte do de Santa Fé, o Fiscal era da opinião que a Real Audiência poderia permitir esse tipo de procedimento e aprovar as diligências que tinham sido adotadas pelo alcalde até aquele momento e emitir uma Real Provisão para que o mesmo pudesse decretar a prisão do marido, "remetendo o réu a este Real cárcere (f.14r).

O Tribunal da Real Audiência, composto pelos Ouvidores em pleno, Cabeza, Velasco, Pareja, Cicerón, Pérez e o Regente do mesmo assinaram um decreto em que se legitimava a jurisdição do Alcalde de Santa Fé e se lhe dava comissão para que substanciasse a causa até deixá-la no estado de sentença.

Mariluz Urquijo, no artigo referido, informa de que em casos muito excepcionais, quando "os juízes de um determinado lugar eram notoriamente incapazes de levarem adiante os processos, a Audiência estendia a jurisdição dos alcaldes de uma cidade próxima até lá. Não se tratava de uma delegação de faculdades feita pelo titular, caso que era bastante frequente, mas de uma alteração disposta pelo próprio Tribunal e que constituía um último recurso ao qual se recorria em casos muito excepcionais" ${ }^{\text {,3 }}$. Parece-me que não era exatamente o caso de uma "incapacidade notória" por parte do alcalde de la Santa Hermandad de São Nicolás, mas de uma analogia da qual o Tribunal poderia servir-se para, de forma arbitrária, proceder dessa forma e nesse caso concreto.

$\mathrm{Na}$ sua denúncia a vítima referia que seu marido dava-lhe com força "açoites, pauladas, bofetadas e pontapés com a crueldade mais acérrima de um homem deixado da mão de Deus, sem temor à igreja nem à justiça" (f.1r) e que se viu obrigada a abandonar a sua casa, que era herança do seu defunto marido, e andar

como peregrina com uma pequena equipagem de umas alforjas, carregadas nos ombros, até encontrar uma casa que me acolhesse ou me ocultasse para libertar-me da sanguinolenta tirania e do assassinato que o meu marido pretende executar cruelmente" (f.1v).

Também informava que havia uma denúncia dela no tribunal eclesiástico de San Nicolás, onde deixava constância de que o seu marido tinha chegado até a cortar as árvores frutíferas da sua horta e tinha abandonado o cuidado do gado e da fazenda apenas com o intuito de prejudicá-la (f.2v) e como, à força de continuados castigos, "não podia falar palavras, deixando-me a pedir esmolas como me vejo até o dia de hoje, pedindo de porta em porta, sem outro amparo que Deus e a Justiça para que ponha remédio" (f.2v). No seu pedido, Pasquala finalizava suplicando que o juiz de Santa Fé acolhesse sua demanda para 
libertá-la "de um louco carniceiro que, não ficando satisfeito da sua presa, destrói e assola tudo quanto encontra pela frente sem satisfazer o seu próprio apetite” (f.3r).

A defesa de Leandro Roldán apoiava-se nas afirmações de que a sua esposa não cuidava da casa como devia, que saía com frequência, indo na casa dos outros, contrariando a vontade dele, que era ela quem tinha mau gênio e não ele e, para concluir, afirmava que

\begin{abstract}
nessa idade já avançada tanto no homem como na mulher não pode haver excessos que tragam alterações ao matrimônio: portanto, se houver discórdias será devido à diversidade dos gênios e ao seu choque. De fato, não posso negar que tenho sido sempre homem brioso e de um natural mau e a minha companheira não estava ignorante com relação a isso, mas ela é um pouquinho pior do que eu, de maneira que sendo ela uma arrogante, intrépida, desaforada, faladora e atrevida não ficamos nunca de acordo, ela diz uma coisa e eu outra (f. 53v).
\end{abstract}

E pediu que o caso fosse resolvido diretamente pela Audiência. Depois das diligências necessárias e de ouvidas as testemunhas, os autos passaram ao Fiscal da Sua Majestade, no criminal, Marquez de la Plata, quem, aos 8 de Fevereiro de 1790, considerando inicialmente que o caso era verdadeiramente singular, emitiu um parecer aconselhando aos Ouvidores da Real Audiência para que, tendo em conta a singularidade do caso e o pedido do réu, "se radique definitivamente de uma vez o conhecimento desta causa nesta Real Audiência porque é o meio mais oportuno para finalizar esta causa" (f.56r). Propunha, portanto, que tanto o réu quanto a vítima fossem citados a comparecerem pessoalmente perante o Tribunal

E, no dia seguinte, 9 de fevereiro, o Tribunal decidiu "mandar trazer os autos a esta Real Sala e Vistos com o exposto pelo senhor Fiscal mandasse radicar a causa neste Superior Tribunal". Infelizmente, ainda não pude encontrar o processo que deve ter corrido perante a Real Audiência de Buenos Aires.

Parece-me que também neste caso estamos diante de um processo singular. Não só pelo fato de que o processo fosse iniciado perante um alcalde sem competência a quem o Tribunal teve de autorizar e estender a sua jurisdição, mas principalmente pela opinião final do Fiscal de que o melhor modo de resolver o litígio seria que a Audiência chamasse a si o processo e convocasse as duas partes para proceder à sentença, e que a Real Audiência assim o fizesse.

O arbítrio dos juízes era, como disse o historiador italiano Meccarelli, um elemento sistemático e estruturante de todo o ordenamento jurídico e processual ${ }^{44}$, mas esse arbítrio era um arbítrio regrado, na expressão utilizada por Ortego Gil, ou seja, o juiz formava a sua íntima convicção e sentenciava de acordo com ela, a partir não só do "alegado e provado", nem a partir apenas da lei, mas também tendo em conta a equidade, a razão e o direito. Como 
o próprio Ortego explica: “o arbítrio judicial podia afastar-se da estrita legalidade, mas nunca traspassar o marco do Direito, nem muito menos da Justiça"45.

É evidente que isso só pode ser entendido se tivermos em conta que "direito" e "justiça" não significavam uma legalidade estrita, nem era decorrência de uma simples dedução daquilo que estivesse determinado em lei. "Direito" era aquilo que era justo ou conveniente ao caso específico e, neste caso, os Ouvidores consideraram, conforme o seu arbítrio, que era conveniente intervir no meio do processo e retirar do juiz a sentença decisória, chamando a si os autos e convocando as partes para o próprio Tribunal proceder à sentença.

\section{Manuela Melo: condenar ao meu marido a contribuir com os alimentos correspondentes à minha qualidade para poder subsistir com decência}

O último processo é uma demanda de divórcio que, naquela altura era apenas um pedido de separação física e, normalmente era tentado na jurisdição eclesiástica, coisa que a vítima também fez simultaneamente.

O caso apresenta duas características peculiares: em primeiro lugar, o alcalde ordinario, D. Manuel Cerrato, que já tinha recebido outras queixas anteriores da vítima contra seu marido, em lugar de iniciar o processo, decidiu dessa vez providenciar para que a vítima se refugiasse no convento das religiosas de Nossa Senhora das Mercês, mas antes enviou-a ao Ouvidor da Real Audiência de Buenos Aires e Alcalde de Corte, Don Sebastián de Velasco, para que ela mesma denunciasse o seu marido perante um dos Ouvidores do Tribunal Supremo. A sentença final do Ouvidor foi assinada pelos outros Ouvidores da Real Audiência.

E, em segundo lugar, a sentença. A vítima, Manuela, propôs na fase final do processo desistir da queixa desde que o seu marido aceitasse uma série de condições e se comprometesse a cumpri-las. O Ouvidor aceitou a desistência da ação, mandou um escrivão para que o marido assinasse formalmente a aceitação das condições da sua mulher e, ainda, multou-o -coisa que nem sequer tinha sido solicitada- numa pena pecuniária.

O processo foi iniciado por iniciativa do próprio Cerrato quem, por meio de uma declaração escrita aos 22 de novembro, informava ao Ouvidor Sebastián de Velasco de como no dia 13 de Novembro de 1876, Manuel Melo, mulher de Sebastián Pérez de Caravaca, procurou-o pedindo ajuda contra seu marido, que acabava de "arrastá-la, dar-lhe pontapés e golpes em plena rua” (f.1r). Nesse escrito, o alcalde ordinario deixava constância de que 
também tinha informado verbalmente ao Ouvidor das diligências que por própria iniciativa tomara depois daquele dia: fora visitar a casa de Manuela, falou com as pessoas do bairro e chegou à conclusão de que o marido não tinha nenhum motivo para maltratá-la como o fazia e formara a sua convicção de que os supostos motivos e acusações que Caravaca tinha contra sua mulher “... tudo eram ilusões e figurações do marido" (f.1r). O Ouvidor ordenou que Cerrato arrestasse imediatamente Caravaca na prisão da cidade.

Foi o Ouvidor Velasco quem ouviu as confissões da vítima e do réu e das muitas testemunhas que foram arroladas e que, unânimes, declararam em favor da vítima. O ponto central da queixa era que nunca dera motivos para os ciúmes infundados do marido quem por isso, maltratava-a quase que diariamente e muitas vezes a ameaçava com matá-la. As testemunhas declararam que, no dia dos fatos, viram efetivamente como o marido batia na mulher em plena rua e que todos "movidos pela curiosidade e atraídos pelos ruídos do alboroto saíram das suas casas para observar a cena, ouvindo as palavras injuriosas que lhe dirigia, chamando-a de puta, arrastada, indigna" (f. 3r). Foram ouvidos como testemunhas, pelo Ouvidor Velasco, quase todos os vizinhos daquela esquina em que aconteceram os fatos, D. José Antonio Ramírez, D. Esteban Romero, Da . Juana Cabrera, D. Eugenio Romero e D Juana Silva, e todos foram unânimes em afirmar que já fazia mais de um ano e meio que, sem motivo algum, viam frequentemente como Sebastián Pérez maltratava e insultava à sua mulher.

A defesa de Sebastián Pérez apoiou-se no argumento comum para a época, e validado pela doutrina, de que o marido detinha um “poder doméstico", e que, portanto,

está autorizado pelas leis a uma moderada educação da sua mulher quando tem fundamentos para isso porque é como um pai que cuida da economia da casa" (f.18r). E, mais, acrescentava ainda que "se houve algum excesso na correção que deu à sua mulher é preciso que Vossa Alteza tenha presente que um marido cheio de justíssimos receios e sufocado na sua honra pudesse exceder com facilidade os limites da moderação (f.18r).

Depois de apresentada a defesa de Caravaca, a defesa de Manuela mudou de estratégia, apresentando, por escrito, a desistência da causa desde que o seu marido aceitasse jurar perante Deus que aceitaria respeitar três condições irrenunciáveis: primeiro, Manuela passaria a viver na casa dos seus pais, separada do seu marido; segundo, o seu marido

deve ser proibido severamente de entrar nesta casa e qualquer intervenção ou comunicação com Manuela até que ela fique convencida de que suas manias fatais acabaram definitivamente" (f. 24v) e, por último, devia ser obrigado a "contribuir com os alimentos correspondentes à sua qualidade para poder subsistir com decência (f. $24 \mathrm{v})$. 
Antes de assinar o termo de desistência, Manuela Melo advertiu que, caso o marido se negasse a aceitar essas condições, ela prosseguiria na causa, usando das suas defesas, conforme era de justiça, em busca do seu desejo de consertar a sua vida e de retomar a sua honra ofendida, exigindo que fosse punido com as penas correspondentes.

O Ouvidor e juiz da causa, antes de proferir a sua sentença, enviou um escrivão à prisão para que o marido tomasse conhecimento das condições impostas pela sua esposa e, depois que Caravaca jurou e assinou a sua aquiescência, o documento foi devolvido ao juiz e a causa ficou pronta para a sentença.

A sentença final, rubricada por todos os ouvidores da Real Audiência de Buenos Aires e não apenas pelo Ouvidor Velasco, confirmava a desistência de Manuela e, portanto, declarava extinto o processo, determinava que se desse liberdade a D. Sebastián Pérez de Caravaca, mas diante

do atropelo e modos escandalosos com que tratou a $\mathrm{D}^{\mathrm{a}}$ Manuela Melo é condenado a pagar 50 pesos aplicados na forma ordinária e nas custas deste processo, sendo apercebido de que à menor queixa de reincidência será enviado por dois anos de desterro ao presídio de Montevideu (f. 37r).

Do ponto de vista legal, diante de uma desistência do acusador ou de uma composição entre as partes, a doutrina comum entendia que, mesmo assim, tendo em conta o bem da República e a vindicta pública, o juiz da causa poderia aplicar uma pena arbitrária ${ }^{46}$. Era uma opinião comum de toda a doutrina processualística do século XVI a afirmação de que os juízes exerciam o seu arbítrio na hora da aplicação da pena. Por isso, como concluía no seu artigo Ortego, "esta opinião comum permite a Meccarelli qualificar a expressão poenas omnes hodie sunt arbitrariae (hoje todas as penas são arbitrárias). Se bem que esse hodie (hoje) prolongou-se, ao menos, durante três séculos" ${ }^{47}$. Nesse sentido, a sentença proferida no caso de Manuela era possível. Contudo, o que chama a atenção é o conteúdo da mesma: por um lado, o réu foi condenado a uma multa pecuniária que não foi solicitada pela acusação e, por outro, a sentença só foi proferida depois que o marido assinou um termo de compromisso, por meio do qual, como dizia o seu advogado, "a minha parte promete que não causará a menor ofensa nem incomodidade a $D^{a}$ Manuela e assim o jura perante Deus Nosso Senhor" (f. 36v).

Parece-me que o Ouvidor quis evitar um conflito de jurisdições que poderia, em tese, ser provocado. A competência originária para julgar sobre separações matrimoniais era da justiça eclesiástica e, neste caso concreto, já havia em curso uma causa no tribunal eclesiástico solicitando-a, portanto, a sentença restringiu-se a punir as lesões corporais, 
evitando antecipar-se ao juízo da Igreja. Contudo, o juízo civil providenciou para que houvesse um compromisso formal e escrito, perante a autoridade civil, e um juramento também formal, perante a autoridade divina, de maneira a que, de fato, ambos vivessem separados e o marido arcasse com os custos de uma vida digna para a sua mulher. Do ponto de vista estritamente legal não seria necessária essa providência, mas do ponto de vista do direito e do justo, parece-me que o juiz agiu conforme o arbítrio da sua consciência tornando possível uma sentença mais justa.

\section{Considerações finais}

O interesse por parte dos historiadores com relação aos processos judiciais tem aumentado consideravelmente nos últimos anos. A análise dos mesmos tem enriquecido muito um conhecimento mais abrangente do período colonial.

A partir da documentação processual é possível verificar como os ritos e as diligências processuais facilitavam ou impediam que os casos em litígio tivessem uma sentença mais justa.

Os três processos aqui apresentados caracterizam-se pela extrema celeridade em que foram concluídos e pelo exercício amplo do arbítrio judicial. Poderia entender-se, como pensam alguns historiadores, que essas características são decorrência do absolutismo crescente da Monarquia hispânica e do inerente desejo de punir. Mas também se pode pensar, como espero ter mostrado, que essas características facilitavam uma sentença mais justa e adequada a cada caso.

A influência da teologia católica e do direito canônico não era propriamente evidente sobre as leis emanadas, mas sobre a forma de pensar o direito. Essa influência era exercida não apenas sobre o Rei e os alcaldes e Ouvidores, mas também sobre o povo. Tendo em conta que o alcalde era mais um e igual a todos os moradores de uma localidade, esperava-se que julgasse não apenas conforme a lei, nem ao alegado e provado, mas, principalmente, conforme aquilo que, em consciência e de acordo com o seu arbítrio, considerasse como mais justo em cada caso concreto.

Parece-me que essa linha de pesquisa, centrada na análise dos processos judiciais, poderá trazer uma luz mais abrangente se quisermos conhecer melhor como se processava e como se fazia justiça na América espanhola dos séculos XVII e XVIII. 


\title{
Notas
}

\begin{abstract}
${ }^{1}$ KLUGER, Viviana, El expediente judicial como fuente para la investigación histórico-jurídica: Su utilidad para el estudio de la historia de la familia colonial iberoamericana. Revista Passagens. Fortaleza, vol.1, nº 1, 2009 , p. 10.

${ }^{2}$ KLUGER, Viviana, El expediente judicial como fuente para la investigación histórico-jurídica: Su utilidad para el estudio de la historia de la familia colonial iberoamericana. Revista Passagens. Fortaleza, vol.1, nº 1, 2009 , p. 10.
\end{abstract}

${ }^{3}$ GHIRARDI, M., Familias, poderes, instituciones y conflictos. Iglesia, preceptos y transgresiones. La vertiente americana. In: CHACÓN JIMÉNEZ, F., HERNÁNDEZ FRANCO, J., E GARCÍA GONZÁLEZ, F., (ed), Familia y organización social en Europa y América, siglos XV-XX. Murcia: Ediciones de la Universidad de Murcia, 2007, p. 109.

${ }^{4}$ GHIRARDI, M., Familias, poderes, instituciones y conflictos. Iglesia, preceptos y transgresiones. La vertiente americana. In: CHACÓN JIMÉNEZ, F., HERNÁNDEZ FRANCO, J., E GARCÍA GONZÁLEZ, F., (ed), Familia y organización social en Europa y América, siglos XV-XX. Murcia: Ediciones de la Universidad de Murcia, 2007, p. 121.

${ }^{5}$ TWINAN, A., Estado de la cuestión. La historia de la familia, la historia del género, pasado, presente y futuro. In: CHACÓN JIMÉNEZ, F., HERNÁNDEZ FRANCO, J., E GARCÍA GONZÁLEZ, F., (ed), Familia y organización social en Europa y América, siglos XV-XX. Murcia: Ediciones de la Universidad de Murcia, 2007, p. 335.

${ }^{6}$ GHIRARDI, M., Familias, poderes, instituciones y conflictos. Iglesia, preceptos y transgresiones. La vertiente americana. In: CHACÓN JIMÉNEZ, F., HERNÁNDEZ FRANCO, J., E GARCÍA GONZÁLEZ, F., (ed), Familia y organización social en Europa y América, siglos XV-XX. Murcia: Ediciones de la Universidad de Murcia, 2007, p. 110.

${ }^{7}$ GHIRARDI, M., Familias, poderes, instituciones y conflictos. Iglesia, preceptos y transgresiones. La vertiente americana. In: CHACÓN JIMÉNEZ, F., HERNÁNDEZ FRANCO, J., E GARCÍA GONZÁLEZ, F., (ed), Familia y organización social en Europa y América, siglos XV-XX. Murcia: Ediciones de la Universidad de Murcia, 2007, p. 111

${ }^{8}$ FUENTES BARRAGÁN, Antonio, Quebrantos de la moral conyugal: amistades ilícitas en el Buenos Aires tardocolonial. Naveg@mérica. Revista electrónica editada por la Asociación Española de Americanistas [en línea]. 2015, n. 15. Disponible en:<http://revistas.um.es/navegamerica>. p. 2.

9 FUENTES BARRAGÁN, Antonio, Sobre estrategias y pasiones: Etnicidad, honor y matrimonio en la Provincia de Buenos Aires (siglo XVIII), Revista Dos Puntas. Buenos Aires, Año VII, nº 12/2015, p. 121.

${ }^{10}$ FUENTES BARRAGÁN, Antonio, "Eses torpes deseos". Delitos y desviaciones sexuales en Buenos Aires, 1760-1810, Estudios de Historia colonial. Buenos Aires, nº 13, 1993, p. 31.

${ }^{11}$ FUENTES BARRAGÁN, Antonio, "Eses torpes deseos". Delitos y desviaciones sexuales en Buenos Aires, 1760-1810, Estudios de Historia colonial. Buenos Aires, nº 13, 1993, p. 32.

${ }^{12}$ AGÜERO, ALEJANDRO, Revista Fontes, São Paulo, no 1, 2014/2, p. 4.

${ }^{13}$ ORTEGO GIL, P. Condenar ou absolver entre os juízes de Castela e o Iudex commune. In: HOMEM, Antonio Pedro Barbas, PINTO, Eduardo Vera-Cruz (cood). O Perfil do juiz na Tradição Ocidental, Coimbra: Almedina, 2009, p. 133.

${ }^{14}$ ORTEGO GIL, P. El arbitrio de los jueces inferiores: su alcance y limitaciones. In: SÁNCHEZ-ARCILLA BERNAL. El arbitrio judicial en el Antiguo Régimen (España e Indias, siglos XVI-XVIII). Madrid: Dykinson, 2012 , p. 148.

${ }^{15}$ ORTEGO GIL, P. El arbitrio de los jueces inferiores: su alcance y limitaciones. In: SÁNCHEZ-ARCILLA BERNAL. El arbitrio judicial en el Antiguo Régimen (España e Indias, siglos XVI-XVIII). Madrid: Dykinson, 2012, p. 149.

${ }^{16}$ LARA, Silvia H. e MENDONÇA, Joseli Maria N., Direitos e Justiças no Brasil. Campinas: Editora Unicamp, 2006, p. 11.

${ }^{17}$ LARA, Silvia H. e MENDONÇA, Joseli Maria N., Direitos e Justiças no Brasil. Campinas: Editora Unicamp, 2006, p. 13.

${ }^{18}$ Mantenho o termo Alcalde ordinario em castelhano e sem aspas por uma questão estética, já que será repetido muitas vezes. 
${ }^{19}$ ALONSO, María Paz. El proceso penal en Castilla (siglos XIII-XVIII). Salamanca: Ediciones Universidad de Salamanca, 1982, p. 159.

${ }^{20}$ ALONSO, María Paz. El proceso penal en Castilla (siglos XIII-XVIII). Salamanca: Ediciones Universidad de Salamanca, 1982 , p. 160.

21 DE LAS HERAS, La justicia penal de los Austrias en la Corona de Castilla. Salamanca: Ediciones Universidad de Salamanca, 1991, p. 175.

${ }^{22}$ DE LAS HERAS, La justicia penal de los Austrias en la Corona de Castilla. Salamanca: Ediciones Universidad de Salamanca, 1991, p. 176.

${ }^{23}$ ALONSO, María Paz. El proceso penal en Castilla (siglos XIII-XVIII). Salamanca: Ediciones Universidad de Salamanca, 1982, p. 163.

${ }^{24}$ ALONSO, María Paz. El proceso penal en Castilla (siglos XIII-XVIII). Salamanca: Ediciones Universidad de Salamanca, 1982, p. 167.

${ }^{25}$ ALONSO, María Paz. El proceso penal en Castilla (siglos XIII-XVIII). Salamanca: Ediciones Universidad de Salamanca, 1982, p. 172.

${ }^{26}$ ALONSO, María Paz. El proceso penal en Castilla (siglos XIII-XVIII). Salamanca: Ediciones Universidad de Salamanca, 1982, p. 170.

${ }^{27}$ ALONSO, María Paz. El proceso penal en Castilla (siglos XIII-XVIII). Salamanca: Ediciones Universidad de Salamanca, 1982, p. 172.

${ }^{28}$ ALONSO, María Paz. El proceso penal en Castilla (siglos XIII-XVIII). Salamanca: Ediciones Universidad de Salamanca, 1982, p. 172.

${ }^{29}$ KLUGER, Viviana. Justicia local y práctica del Derecho en el Virreinato del Río de la Plata (1776-1810). Una mirada desde la justicia letrada y la justicia lega. Trocadero, (18), 2006, pp. 203-223.

${ }^{30}$ KLUGER, Viviana. Justicia local y práctica del Derecho en el Virreinato del Río de la Plata (1776-1810). Una mirada desde la justicia letrada y la justicia lega. Trocadero, (18), 2006, p. 205.

${ }^{31}$ PUGLIESE, María Rosa. De la justicia lega a la justicia letrada. Abogados y Asesores en el Río de la Plata, 1776-1821. Buenos Aires: Junta de estudios históricos de San José de Flores, 2000, p. 9.

${ }^{32}$ KLUGER, Viviana. Justicia local y práctica del Derecho en el Virreinato del Río de la Plata (1776-1810). Una mirada desde la justicia letrada y la justicia lega. Trocadero, (18). Cádiz, 2006, p. 208.

33 ORTEGO GIL, Pedro. El arbitrio de los jueces inferiores: su alcance y limitaciones. In: SÁNCHEZARCILLA BERNAL. El arbitrio judicial en el Antiguo Régimen (España e Indias, siglos XVI-XVIII). Madrid: Dykinson, 2012, p. 133-134.

${ }^{34}$ ALONSO, María Paz. El proceso penal en Castilla (siglos XIII-XVIII). Salamanca: Ediciones Universidad de Salamanca, 1982, p. 172.

35 Sobre o debate em torno da motivação das sentenças, que neste espaço não caberia, veja-se ALISTE SANTOS, La motivación de las resoluciones judiciales. Madrid: Marcial Pons, 2011 e GARRIGA ACOSTA, Carlos e LORENTE SARIÑENA, Marta María. El juez y la Ley: La motivación de las sentencias (Castilla, 1489-España, 1855). Anuario de la Facultad de Derecho de la Universidad Autónoma de Madrid. Madrid, n. 1, 1997, pp. 97-144. Com relação à América espanhola, podem ser interessantes LEVAGGI, Abelardo. La fundamentación de las sentencias en el Derecho Indiano. Revista de Historia del Derecho. Buenos Aires, n. 6, 1978, pp. 45-73 e MARILUZ URQUIJO, José María. La acción de sentenciar a través de los apuntes de Benito de La Mata Linares. Revista de Historia del Derecho, Buenos Aires, n. 4, 1976, pp. 141-160.

${ }^{36}$ MARTIRÉ, Eduardo. Las Audiencias y la administración de justicia en las Indias. Del iudex perfectus al iudex solutus. Buenos Aires: Librería Histórica, 2009, p. 72.

${ }^{37}$ MARILUZ URQUIJO, La Real Audiencia de Buenos Aires y la administración de justicia en lo criminal en el interior del Virreinato. In: Primer Congreso de Historia de los Pueblos de la Provincia de Buenos Aires, La Plata, Ministerio de Gobierno de la Provincia de Buenos Aires, 1952, Tomo II, p. 271.

${ }^{38}$ MARILUZ URQUIJO, La Real Audiencia de Buenos Aires y la administración de justicia en lo criminal en el interior del Virreinato. In: Primer Congreso de Historia de los Pueblos de la Provincia de Buenos Aires, La Plata, Ministerio de Gobierno de la Provincia de Buenos Aires, 1952, Tomo II, p. 272.

${ }^{39}$ MARILUZ URQUIJO, La Real Audiencia de Buenos Aires y la administración de justicia en lo criminal en el interior del Virreinato. In: Primer Congreso de Historia de los Pueblos de la Provincia de Buenos Aires, La Plata, Ministerio de Gobierno de la Provincia de Buenos Aires, 1952, Tomo II, p. 272.

${ }^{40}$ Archivo Histórico de la Provincia de Buenos Aires, Criminal Provincial, Legajo 66, 5.5.66.38. Criminales contra Alexandro Yllescas, Año 1788.

${ }^{41}$ Archivo Histórico de la Provincia de Buenos Aires, Criminal Provincial, Legajo 88, 7.1.88.43, Año 1789, Causa criminal contra Leandro Roldan a pedimiento de su muger D ${ }^{a}$ Pasquala Gonzalez. 


\footnotetext{
${ }^{42}$ Archivo Histórico de la Provincia de Buenos Aires, Legajo, 78, 5.5.78.9. Causa criminal contra Sebastián Pérez de Caravaca por maltratar su mujer, Año 1786.

${ }^{43}$ MARILUZ URQUIJO, La Real Audiencia de Buenos Aires y la administración de justicia en lo criminal en el interior del Virreinato. In: Primer Congreso de Historia de los Pueblos de la Provincia de Buenos Aires, La Plata, Ministerio de Gobierno de la Provincia de Buenos Aires, 1952, Tomo II, p. 287.

${ }^{44}$ MECARELLI, M. Massimo. Arbitrium Un aspetto sistematico degli ordinamenti giuridici in età di diritto comune. Milão: Giuffrè, 1998.

${ }^{45}$ ORTEGO GIL, P., El arbitrio de los jueces: su alcance y limitaciones. In: SÁNCHEZ-ARCILLA BERNAL. El arbitrio judicial en el Antiguo Régimen (España e Indias, siglos XVI-XVIII). Madrid: Dykinson, 2012, p.180.

${ }^{46}$ ORTEGO GIL, P., El arbitrio de los jueces: su alcance y limitaciones. In: SÁNCHEZ-ARCILLA BERNAL. El arbitrio judicial en el Antiguo Régimen (España e Indias, siglos XVI-XVIII). Madrid: Dykinson, 2012, p. 179.

${ }^{47}$ ORTEGO GIL, P., El arbitrio de los jueces: su alcance y limitaciones. In: SÁNCHEZ-ARCILLA BERNAL. El arbitrio judicial en el Antiguo Régimen (España e Indias, siglos XVI-XVIII). Madrid: Dykinson, 2012, p.179.
}

\section{Referências Bibliográficas}

AGÜERO, Alejandro. El testimonio procesal y la administración de justicia penal en la periferia de la Monarquía Católica, siglos XVII y XVIII. Revista Fontes, São Paulo, no ${ }^{\circ}$, 2014/2, pp. 3-14.

ALISTE SANTOS, Tomás-Javier. La motivación de las resoluciones judiciales. Madrid: Marcial Pons, 2011.

ALONSO, MARÍA PAZ, El proceso penal en Castilla (siglos XIII-XVIII), Ediciones Universidad de Salamanca, Salamanca, 1982.

BARRIOS PINTADO, Feliciano (Ed). Derecho y administración pública en las Indias hispánicas: Actas del XII Congreso internacional de Historia del Derecho indiano. Cuenca: Cortes de Castilla-La Mancha/Universidad de Castilla-La Mancha, 2002, 2 vol.

DE LAS HERAS SANTOS, José A. La justicia penal de los Austrias en la Corona de Castilla. Salamanca: Ediciones Universidad de Salamanca, 1991

FUENTES BARRAGÁN, Antonio. Quebrantos de la moral conyugal: amistades ilícitas en el Buenos Aires tardocolonial. Naveg@mérica. Revista electrónica editada por la Asociación Española de Americanistas [en línea]. 2015, n. 15. Disponible en:<http://revistas.um.es/navegamerica>. Consulta em 25/04/2017.

FUENTES BARRAGÁN, Antonio. Sobre estrategias y pasiones: Etnicidad, honor y matrimonio en la Provincia de Buenos Aires (siglo XVIII), Revista Dos Puntas. Buenos Aires, Año VII, no 12/2015.

FUENTES BARRAGÁN, Antonio. "Eses torpes deseos". Delitos y desviaciones sexuales en Buenos Aires, 1760-1810, Estudios de Historia colonial. Buenos Aires, nº 13, 1993.

GARRIGA ACOSTA, Carlos; LORENTE SARIÑENA, Marta María. "El juez y la Ley: La motivación de las sentencias (Castilla, 1489-España, 1855). Anuario de la Facultad de Derecho de la Universidad Autónoma de Madrid, Madrid, n. 1, 1997, pp. 97-144.

GHIRARDI, M. Familias, poderes, instituciones y conflictos. Iglesia, preceptos y transgresiones. La vertiente americana. In: CHACÓN JIMÉNEZ, F., HERNÁNDEZ FRANCO, J., E GARCÍA GONZÁLEZ, F., (ed), Familia y organización social en Europa y América, siglos XV-XX. Murcia: Ediciones de la Universidad de Murcia, 2007.

GROSSI, Paolo. Mitología jurídica de la Modernidad, Traducción de Manuel Martínez Neira. Madrid, Ed. Trotta, 2003.

GUZMÁN, Alejandro. Decisión de controversias jurisprudenciales y codificación del Derecho en la época moderna. Madrid, Anuário de Historia del Derecho español, 1980. 
HOMEM, António Pedro Barbas et alii (coord), O perfil do juiz na tradição ocidental, Almedina, Lisboa, 2007.

KLUGER, Viviana. El expediente judicial como fuente para la investigación históricojurídica: Su utilidad para el estudio de la historia de la familia colonial iberoamericana. Revista Passagens. Fortaleza, vol.1, nº 1, 2009.

KLUGER, Viviana. Justicia local y práctica del Derecho en el Virreinato del Río de la Plata (1776-1810). Una mirada desde la justicia letrada y la justicia lega. Trocadero, (18), 2006.

LARA, Silvia H. e MENDONÇA, Joseli Maria N. Direitos e Justiças no Brasil. Campinas: Editora Unicamp, 2006.

LEVAGGI, Abelardo. "La fundamentación de las sentencias en el Derecho Indiano". Revista de Historia del Derecho, Buenos Aires, n. 6, 1978, pp. 45-73.

LUQUE TALAVÁN, Miguel. Un universo de opiniones. La Literatura jurídica indiana. C.S.I.C., Madrid, 2003.

MARILUZ URQUIJO, José María. "La acción de sentenciar a través de los apuntes de Benito de La Mata Linares”. Revista de Historia del Derecho, Buenos Aires, n. 4, 1976, pp. 141 160.

MARILUZ URQUIJO, José M. La Real Audiencia de Buenos Aires y la administración de justicia en lo criminal en el interior del Virreinato. In: Primer Congreso de Historia de los Pueblos de la Provincia de Buenos Aires, La Plata, Ministerio de Gobierno de la Provincia de Buenos Aires, 1952, Tomo II.

MARTIRÉ, Eduardo. Las Audiencias y la administración de justicia en las Indias. Del iudex perfectus al iudex solutus. Buenos Aires: Librería Histórica, 2009.

MECCARELLI, Massimo, Arbitrium Un aspetto sistematico degli ordinamenti giuridici in età di diritto comune. Milão: Giuffrè, 1998.

ORTEGO GIL, Pedro. "Sentencias criminales en Castilla: entre jueces y abogados". Clío \& Crimen. Revista del Centro de Historia del Crimen de Durango. Durango, n. 10, 2013, pp. 359-372.

ORTEGO GIL, Pedro. El arbitrio de los jueces inferiores: su alcance y limitaciones, in SÁNCHEZ-ARCILLA BERNAL, El arbitrio judicial en el Antiguo Régimen (España e Indias, siglos XVI-XVIII). Dykinson: Madrid, 2012.

ORTEGO GIL, P. Condenar ou absolver entre os juízes de Castela e o Iudex commune. In: HOMEM, Antonio Pedro Barbas, PINTO, Eduardo Vera-Cruz (cood). O Perfil do juiz na Tradição Ocidental. Coimbra: Almedina, 2009, p. 133.

PUGLIESE, María Rosa. De la justicia lega a la justicia letrada. Abogados y Asesores en el Río de la Plata, 1776-1821. Buenos Aires: Junta de estudios históricos de San José de Flores, 2000.

TWINAN, A. Estado de la cuestión. La historia de la familia, la historia del género, pasado, presente y futuro. In: CHACÓN JIMÉNEZ, F., HERNÁNDEZ FRANCO, J., E GARCÍA GONZÁLEZ, F., (ed), Familia y organización social en Europa y América, siglos XV-XX. Murcia: Ediciones de la Universidad de Murcia, 2007.

\section{Fontes}

Archivo Histórico de la Provincia de Buenos Aires, Criminal Provincial, Legajo 66, 5.5.66.38. Criminales contra Alexandro Yllescas, Año 1788.

Archivo Histórico de la Provincia de Buenos Aires, Criminal Provincial, Legajo 88, 7.1.88.43, Año 1789, Causa criminal contra Leandro Roldan a pedimiento de su muger $D^{a}$ Pasquala Gonzalez. 
Archivo Histórico de la Provincia de Buenos Aires, Legajo, 78, 5.5.78.9. Causa criminal contra Sebastián Pérez de Caravaca por maltratar su mujer, Año 1786. 